\title{
Jejunum and Ileum Neuroendocrine Tumor Pathologic Distant Metastasis TNM
} Finding v8

National Cancer Institute

\section{Source}

National Cancer Institute. Lejunum and Ileum Neuroendocrine Tumor Pathologic Distant Metastasis TNM Finding v8. NCI Thesaurus. Code C135102.

A pathologic finding about one or more characteristics of a jejunum and ileum neuroendocrine tumor, following the rules of the TNM AJCC v8 classification system as they pertain to distant metastases. 